\title{
Effect of harvesting age and plant spacing on growth, yield and yield component of Lavender (Lavandula angustifolia L.) under Rainfed condition at Hawassa, Southern Ethiopia
}

\author{
Basazinew Degu*, Sulti Amano
}

\author{
Ethiopian Institute of Agricultural Research, Wondo Genet Agricultural Research Center, P.O. Box 198, \\ Shashemene, Ethiopia.
}

*Corresponding Authors: Basazinew Degu, Ethiopian Institute of Agricultural Research, Wondo Genet Agricultural Research Center, P.O. Box 198, Shashemene, Ethiopia.

\begin{abstract}
The experiment was carried out at Hawassa, Southern Ethiopia during 2017 and 2018 cropping season under rainfed condition to investigate the optimum harvesting age and plant spacing for growth, yield and yield component of lavender under rainfed condition. The experiment consisted of four levels of intra-row spacing (45, 60, 75 and $90 \mathrm{~cm}$ ) with inter-row spacing of $60 \mathrm{~cm}$ and three levels of harvesting ages after transplanting (9, 10 and 11 MAT). The experiment laid out in Randomized Complete Block Design (RCBD) with three replications as factorial arrangement. The results of combined analysis of variance revealed that, spacing had a significant influence on number of branches per plant, fresh leaves and flower weight/plant, fresh leaves and flower yield/ha and essential oil yield/ha. The highest number of branches/plant (180.7) and fresh leaves and flower weight/plant $(755.39 \mathrm{~g})$ was obtained at spacing of $60 * 90 \mathrm{~cm}$; fresh leaves and flower yield/ha $(21.12 \mathrm{t})$ and essential oil yield/ha $(119.2 \mathrm{~kg})$ was obtained at a spacing of $60 * 45 \mathrm{~cm}$. Whereas, harvesting age exerted a significant influence on essential oil content and essential oil yield in $\mathrm{kg} / \mathrm{ha}$, but not on the other traits. The highest essential oil content (0.67\%) and essential oil yield/ha (115.5 kg) were obtained at 11 MAT. Moreover, the interaction effect did not significantly influence all the tested parameters. Therefore, it was concluded that further investigation is needy by adding additional levels of harvesting age above 11MAT to investigate at which age the essential oil yield/ha will be declined. But, for the time being until another investigation obtained, at Hawassa and a place where having similar agroecology, it is highly recommended to plant Lavender at a spacing of $60^{*} 45 \mathrm{~cm}$ and harvest it at 11 MAT to get the highest essential oil yield/ha.
\end{abstract}

Keywords: Essential oil content, Essential oil yield, Harvesting age, Plant spacing

\section{INTRODUCTION}

Lavender (Lavandula angustifolia L.) is a perennial shrub which belongs to the mint family Lamiaceae. It is native to southern Europe and the Mediterranean area and is commercially cultivated in France, Spain, Portugal, Hungary, the UK, Bulgaria, Australia, China and the USA (Shawl and kumar, 2000). It is cultivated for its aromatic inflorescence from which the essential oil is isolated, although its fresh and dried flowers are also marketed (Renaud et al., 2001).

The essential oil of this species is commonly used in aromatherapy and massage. Its major clinical benefits are on the central nervous system (Chu and Kemper, 2001). The essential oil is also known for its excellent aroma and is extensively used in the perfumery, flavor and cosmetic industries. The oil is known to possess sedative, carminative, anti-depressive and anti-inflammatory properties (Cavanagh and Wilkinson, 2005). Chu and Kemper (2001) also stated that, Lavender extracts have traditionally been prescribed to treat infertility,infection, anxiety and fever, and have been used as antidepressants, antispasmodics, anti-flatulent agents, antiemetic remedies and diuretics. Its essential oil has gained a strong reputation in aromatherapy and as holistic relaxant to treat stress, anxiety, depression, fatigue or insomnia (Chu and Kemper, 2001). Studies suggest that lavender aroma during recesses prevents deterioration of work performance (Sakamoto et al., 2005) and might improve memory and cognition in Alzheimer's patients (Adsersen et al., 2005).

The growth, yield and yield components of plants are determined by a series of factors including plant genetic (Shafie et al., 2009), climate, edaphic, elevation, topography and also an interaction of various factors (Rahimmalek et al., 2009). Among these factors crop management practices such as harvesting age and plant spacing are included. Plant spacing and harvesting age had an effect on growth, biomass and oil yield of Artemisia (Zewdinesh et al., 2011) and Rose-scented geranium 
(Haileslassie and Kebede, 2015). Harvesting age had an effect on yield and yield related traits of lemongrass (Jimayu et al., 2016; Lulie and Chala, 2016; Jimayu and Gebre, 2017).

Even if it has many uses, there is a limited finding regarding to the agronomic management practices of lavender cultivating under rainfed condition in worldwide including Ethiopia. This would result cultivation of the crop without knowing its appropriate management practices. This leads to reduction of the production and productivity of lavender. Though, research is useful to minimize the reduction of growth, yield and yield components of lavender. Therefore, the objective of this paper was to investigate optimum harvesting age and plant spacing for growth, yield and yield component of Lavandula angustifolia $\mathrm{L}$. under rainfed condition.

\section{MATERIALS AND METHODS}

\subsection{Description of the Study Area}

The study was conducted at Hawassa Agricultural Research Center experimental field, Southern Ethiopia during 2017 and 2018 cropping seasons under rainfed condition. The center is located at latitude $7^{\circ} 05^{\prime} \mathrm{N}$ and longitude $39^{\circ} 29^{\prime} \mathrm{E}$ with an altitude of 1700 meters above sea level (m.a.s.l.). The area receives mean annual rainfall of $964 \mathrm{~mm}$ with mean maximum and minimum temperatures of $27.34^{\circ} \mathrm{C}$ and $12.94^{\circ} \mathrm{C}$, respectively. The soil textural class of the study area is sandy loam with $\mathrm{pH}$ of 7.2.These environmental conditions are conducive for lavender cultivation.

\subsection{Plant Materials, Experimental Design and Field Management}

Lavender (Variety WG-Lavender-II) was planted at different intra spaced $(45,60,75$ and $90 \mathrm{~cm})$ with inter-raw spacing of $60 \mathrm{~cm}$ at Hawassa in South Ethiopia were harvested at three different months after transplant $(9,10$ and 11 MAT) used for the study. The experiment was laid by using randomized complete block design with three replications as factorial arrangement. The gross plot size of each treatment was $3.6 \mathrm{~m} \times 3.6 \mathrm{~m}$. The distance between plots and replications was $1 \mathrm{~m}$ and $2 \mathrm{~m}$, respectively. Healthy and uniform seedlings were transplanted from the nursery to the open field condition after two months of establishment. Transplanting of seedlings was taken place at the commencement of main rainy season after the land prepared well. Proper hoeing, watering and weeding were carried out as required.

\subsection{Data Collection}

During the study the following data were collected. The characters that manifested for data collection are:

Plant height: It was measured in centimeter from the base of the randomly selected plants to tip of the main stem by using tape meter; then the average height was determined.

Number of branches per plant:The total numbers of branches arising from the main stem were counted manually and average value was determined.

Fresh leaf and flower weight/plant (g): The average fresh leaf and flower weight of the randomly selected plants was immediately recorded after the leaves and flowers were separated from stem.

Fresh leaves and flower yield (t/ha): All plants from the central rows of each plot were harvested and fresh leaf and flower yield per net plot was estimated and then converted in to tones per hectare.

Essential oil content (\%): Essential oil content was obtained by hydro-distillation, according to the procedure described by Daniel et al. (2009).The fresh leaves and flower of lavender were placed in round bottom flask and subjected to hydro-distillation in a Clevenger apparatus. Then, harvested plants were separated into leaf, flower and stem,fresh leaves and flowers having biomass of 300 gcomposite sample was charged in the Clevenger apparatus along with $700 \mathrm{ml}$ of water and trapped for 3 hours. Water was poured in to the flask until the plant part submersed completely. The flask was placed on the heating mantle and the water and plant sample could boil for 3 hours and the essential oil were collected and measured by using pipette reading. The percentage of essential oil content was determined by the following formula.

$$
\text { Essential oil content }\left(\% \frac{w}{w} \text { fresh basis }\right)=\text { Weight of oil } X 100 / \text { Weight of sample }
$$

Essential oil yield ( $\mathrm{kg} / \mathbf{h a}$ ): The volume of essential oil collected in the collecting tube of the apparatus dehydrated, measured and expressed on weight by weight (\%w/w) fresh basis. Then the essential oil yield/ha was determined by the following formula. 
Effect of harvesting age and plant spacing on growth, yield and yield component of Lavender (Lavandula angustifolia L.) under Rainfed condition at Hawassa, Southern Ethiopia

Essential oil yield $\left(\frac{\mathrm{kg}}{\mathrm{ha}}\right)=$ Fresh leaves and flower yield $\left(\frac{\mathrm{kg}}{\mathrm{ha}}\right)$

$X$ Essential oil content $(\% w / w) / 100$

\subsection{Data Analysis}

The collected data were subjected to analysis of variance (ANOVA) using SAS version 9.0 (SAS, 2000) statistical software packages. Means were separated using the Least Significant Difference (LSD) procedure at the 5\% and $1 \%$ level of significance.

The following meteorological data were collected from Hawassa during 2017 to 2018 (Table 1).

Table1. Mean monthly maximum and minimum temperature $\left({ }^{\circ} \mathrm{C}\right)$; and Mean monthly rainfall (mm) at Hawassa trial site during 2017 and 2018 cropping seasons

\begin{tabular}{|l|l|l|l|l|l|l|}
\hline \multirow{3}{*}{ Month } & \multicolumn{3}{|l|}{ Mean monthly temperature $\left({ }^{\mathbf{0}} \mathbf{C}\right)$} & \multicolumn{2}{l|}{$\begin{array}{l}\text { Mean monthly rainfall } \\
(\mathbf{m m})\end{array}$} \\
\cline { 2 - 8 } & $\mathbf{2 0 1 7}$ & $\mathbf{2 0 1 8}$ & $\mathbf{2 0 1 7}$ & $\mathbf{2 0 1 8}$ \\
\cline { 2 - 7 } & Max. & Min. & Max. & 11.43 & 0.00 & 0.14 \\
\hline January & 29.00 & 9.75 & 29.18 & 13.28 & 3.16 & 2.19 \\
\hline February & 29.90 & 14.49 & 30.23 & 13.93 & 2.94 & 4.22 \\
\hline March & 31.56 & 14.49 & 28.34 & 15.63 & 2.95 & 9.20 \\
\hline April & 31.60 & 14.78 & 26.65 & 15.65 & 7.78 & 3.55 \\
\hline May & 28.40 & 15.82 & 27.76 & 15.50 & 1.95 & 6.30 \\
\hline June & 27.73 & 15.49 & 25.12 & 15.16 & 5.49 & 7.59 \\
\hline July & 26.10 & 16.03 & 34.16 & 15.20 & 3.84 & 5.41 \\
\hline August & 26.61 & 15.53 & 34.08 & 14.34 & 6.01 & 2.20 \\
\hline September & 26.34 & 15.56 & 25.68 & 13.86 & 4.29 & 1.68 \\
\hline October & 27.94 & 15.12 & 27.75 & 13.04 & 0.21 & 4.99 \\
\hline November & 28.49 & 11.69 & 27.50 & 11.65 & 0.00 & 0.22 \\
\hline December & 28.32 & 9.43 & 28.29 & & & \\
\hline
\end{tabular}

(Source: NMA Hawassa Branch)

\section{RESULT AND DISCUSSION}

\subsection{Plant Height (cm)}

Plant height was significantly ( $p<0.05$ ) affected by plant spacing in 2017 cropping season .In 2017 cropping season, the highest $(85.11 \mathrm{~cm})$ and least $(77.33 \mathrm{~cm})$ plant height was obtained at $60 * 75 \mathrm{~cm}$ and $60 * 45 \mathrm{~cm}$, respectively (Table 2). Whereas, it didn`t significantly ( $>0.05$ ) affected by plant spacing in 2018 cropping season and combined result (Table 2).Supporting result obtained by ElNaim et al. (2012) who showed that crop density had no significant effect on plant height of roselle. Contrasting result was reported by Zewdinesh et al. (2011) on Artemisia and Degu and Tesfaye (2015) on Roselle who showed that an increase in planting population markedly would increase plant height.

Harvesting age did not significantly ( $>>0.05)$ affect plant height (Table 2). Contrasting result was reported by Zewdinesh et al. (2011) on Artemisia and Haileslassie and Kebede (2015) on rose-scented geranium. This could be due to the consistence of plant height at each level of harvesting age.

The interaction of plant spacing and harvesting age had a significant $(\mathrm{p}<0.05)$ effect on plant height in 2018 cropping season (Table 2). The highest $(79.8 \mathrm{~cm}$ ) plant height was obtained when lavender was planted at plant spacing of $60 * 90 \mathrm{~cm}$ and harvested at 10 MAT; while, the least $(65.73 \mathrm{~cm})$ was obtained when it was planted at plant spacing of $60 * 90 \mathrm{~cm}$ and harvested at 11 MAT (Table 5).Based on the combined result, the interaction effect did not significantly ( $>0.05)$ affect plant height (Table 2). Similar result was reported by Haileslassie and Kebede (2015) on rose-scented geranium

Table2. Effect of plant spacing and harvest age on plant height (cm) and number of branches per plant of L. angustifolia L. at Hawassa during 2017 and 2018 
Effect of harvesting age and plant spacing on growth, yield and yield component of Lavender (Lavandula angustifolia L.) under Rainfed condition at Hawassa, Southern Ethiopia

\begin{tabular}{|l|l|l|l|l|l|l|}
\hline \multirow{2}{*}{$\begin{array}{l}\text { Treatment } \\
\text { Statistics }\end{array}$} & \multicolumn{4}{|l|}{ Plant height $(\mathbf{c m})$} & \multicolumn{2}{l|}{ Number of branches per plant } \\
\cline { 2 - 7 } & 2017 & 2018 & Combined mean & 2017 & 2018 & Combined mean \\
\hline Plant spacing (cm) & & & & & & \\
\hline $\mathbf{6 0} * \mathbf{4 5}$ & $77.33^{\mathrm{b}}$ & 72.04 & 74.69 & 97.64 & $174.5^{\mathrm{b}}$ & $136.09^{\mathrm{c}}$ \\
\hline $\mathbf{6 0} * \mathbf{6 0}$ & $78.40^{\mathrm{b}}$ & 73.22 & 75.81 & 107 & $210.76^{\mathrm{a}}$ & $158.88^{\mathrm{b}}$ \\
\hline $\mathbf{6 0}$ *75 & $85.11^{\mathrm{a}}$ & 71.42 & 78.27 & 113 & $221.51^{\mathrm{a}}$ & $167.26^{\mathrm{ab}}$ \\
\hline $\mathbf{6 0} * \mathbf{9 0}$ & $82.31^{\text {ab }}$ & 71.44 & 76.88 & 120.2 & $241.2^{\mathrm{a}}$ & $180.7^{\mathrm{a}}$ \\
\hline LSD (0.05) & $\mathbf{5 . 6 5}$ & $\mathbf{5 . 6}$ & $\mathbf{4 . 7 4}$ & $\mathbf{1 6 . 2 9}$ & $\mathbf{3 2 . 3 9}$ & $\mathbf{2 0 . 4 1}$ \\
\hline Significance & $*$ & $\mathbf{N S}$ & $\mathbf{N S}$ & $\mathbf{N S}$ & $* *$ & $* *$ \\
\hline Harvest age (MAT) & & & & & & \\
\hline $\mathbf{9}$ & 78.22 & 71.02 & 74.62 & 104.60 & 220.28 & 162.44 \\
\hline $\mathbf{1 0}$ & 83.75 & 72.72 & 78.23 & 113.02 & 222.80 & 167.91 \\
\hline $\mathbf{1 1}$ & 80.4 & 72.37 & 76.38 & 110.77 & 192.92 & 151.84 \\
\hline LSD (0.05) & $\mathbf{4 . 8 9}$ & $\mathbf{4 . 8 5}$ & $\mathbf{4 . 1}$ & $\mathbf{1 4 . 1 1}$ & $\mathbf{2 8 . 0 5}$ & $\mathbf{1 7 . 6 7}$ \\
\hline Significance & $\mathbf{N S}$ & $\mathbf{N S}$ & $\mathbf{N S}$ & $\mathbf{N S}$ & $\mathbf{N S}$ & $\mathbf{N S}$ \\
\hline Spa*HA & $\mathbf{N S}$ & $*$ & $\mathbf{N S}$ & $\mathbf{N S}$ & $\mathbf{N S}$ & $\mathbf{N S}$ \\
\hline CV $(\%)$ & $\mathbf{7 . 1 5}$ & $\mathbf{7 . 9 5}$ & $\mathbf{6 . 3 4}$ & $\mathbf{1 5 . 2 2}$ & $\mathbf{1 5 . 6 3}$ & $\mathbf{1 2 . 9 9}$ \\
\hline
\end{tabular}

Means with the same letter at the same column are not significantly different.

Where, MAT $=$ Months after transplanting, LSD $=$ Least significance difference, $\mathrm{CV}=$ Coefficient of variation, $\mathrm{Spa}=$ Spacing, $\mathrm{HA}=$ Harvesting age, $\mathrm{NS}=$ Nonsignificant at $\mathrm{p}<0.05, *=$ Significant at $\mathrm{p}<0.05$ and $* *=$ Significant at $\mathrm{p}<0.01$ probability level.

\section{Number of Branches per plant}

Number of branches per plant didn`t significantly ( $p>0.05$ ) affected by plant spacing in 2017 cropping season; whereas, it was significantly $(\mathrm{p}<0.01)$ affected by plant spacing in 2018 cropping season and combined result (Table 2). Based on the combined result, the highest (180.7) and least (136.09) number of branches per plant was obtained at $60 * 90 \mathrm{~cm}$ and $60 * 45 \mathrm{~cm}$ plant spacing, respectively (Table 2). At the widest spacing, there is reduced competition of plants for light, water and nutrients as compared to the closest spacing. Though, this would result an increase in number of branches per plant.

The main effect harvesting age did not significantly ( $>0.05$ ) affect number of branches per plant (Table 2). Supporting result was reported by Zewdinesh et al. (2011) on Artemisia.

Likewise, interaction of the both factors did not significantly ( $>0.05)$ affect number of branches per plant (Table 2). Similar result was reported by Zewdinesh et al. (2011) on Artemisia and Haileslassie and Kebede (2015) on rose-scented geranium.

\section{Fresh leaves and flower weight/plant (g)}

Fresh leaves and flower weight/plant was significantly $(\mathrm{p}<0.01)$ affected by plant spacing during the cropping seasons (Table 3). The same result was reported by Tadesse et al. (2016) on Stevia. Based on the combined result, the highest $(755.39 \mathrm{~g})$ and least $(570.08 \mathrm{~g})$ fresh leaves and flower weight/plant was obtained at $60 * 90 \mathrm{~cm}$ and $60 * 45 \mathrm{~cm}$ plant spacing, respectively (Table 3). As plant spacing increases, fresh leaves and flower weight/plant was increased and vice versa. This might be due to reduced competition of plants for light, water and nutrients in widest spacing would result in an increase in fresh leaves and flower weight/plant.

Fresh leaves and flower weight/plant was significantly $(\mathrm{p}<0.001)$ affected by harvesting age in 2017 cropping season. The highest $(598 \mathrm{~g})$ and least (456.02 $\mathrm{g}$ ) fresh leaves and flower weight/plant was obtained at $60 * 90 \mathrm{~cm}$ and $60 * 45 \mathrm{~cm}$ plant spacing, respectively (Table 3 ). Whereas, it didn`t significantly ( $>0.05$ ) affected by harvesting age in 2018 cropping season and combined result (Table 3).

Likewise, fresh leaves and flower weight/plant was significantly $(\mathrm{p}<0.05)$ affected by the interaction of plant spacing and harvesting age in 2017 cropping season (Table 3). The highest (782.05 g) fresh leaves and flower weight/plant was obtained when lavender was planted at a spacing of $60 * 90 \mathrm{~cm}$ and harvested at 10 MAT; whereas, the least $(441.1 \mathrm{~g})$ fresh leaves and flower weight/plant was obtained when it was planted at a spacing of $60 * 45 \mathrm{~cm}$ and harvested at 10 MAT (Table 6). However, in 2018 
Effect of harvesting age and plant spacing on growth, yield and yield component of Lavender (Lavandula angustifolia L.) under Rainfed condition at Hawassa, Southern Ethiopia

cropping season and the combined result showed that, the interaction of both factors did not significantly ( $>0.05)$ affect fresh leaves and flower weight/plant (Table 3 ).

\section{Fresh leaves and flower yield (t/ha)}

Plant spacing had a significant $(\mathrm{p}<0.001)$ effect on fresh leaves and flower yield/ha during the cropping seasons and combined result (Table 3). Supporting result was reported by Haileslassie and Kebede (2015) on rose-scented geranium and Jimayu et al. (2016) on Lemongrass. Based on the combined result, the highest (21.12 t) and least (13.99 t) fresh leaves and flower yield/ha was obtained at $60 * 45 \mathrm{~cm}$ and $60 * 90 \mathrm{~cm}$ plant spacing, respectively (Table 3). At the closest spacing, fresh leaves and flower yieldwas increased and vice versa. This might be due to the presence of many plants per unit area, this would result in an increase in fresh leaves and flower yield/ha.

As to fresh leaves and flower weight/plant, fresh leaves and flower yield/ha was significantly $(p<0.01)$ affected by harvesting age in 2017 cropping season. The highest $(15.09 \mathrm{t})$ and least $(12.11 \mathrm{t})$ fresh leaves and flower yield /ha was obtained at 10 and 9 MAT, respectively (Table 3). Whereas, harvesting age had not a significant ( $>>0.05)$ effect on fresh leaves and flower yield/ha in 2018 cropping season and combined result (Table 3). This result is contradicted with the findings of Beemnet et al. (2011) on peppermint and Haileslassie and Kebede (2015) on rose-scented geranium.

The interaction of plant spacing and harvesting age not significantly $(\mathrm{p}>0.05)$ affect fresh leaves and flower yield/ha (Table 3). Similar result was reported by Beemnet et al. (2011) on peppermint. In the contrary, the contradicted finding was reported by Haileslassie and Kebede (2015) on rose-scented geranium

Table3. Effect of plant spacing and harvest age on fresh leaves and flower weight per plant $(g)$ and fresh leaves and flower yield (t/ha) of L. angustifolia L. at Hawassa during 2017 and 2018

\begin{tabular}{|c|c|c|c|c|c|c|}
\hline \multirow{2}{*}{$\begin{array}{ll}\text { Treatment } & \& \\
\text { Statistics } & \end{array}$} & \multicolumn{3}{|c|}{ Fresh leaves and flower weight/plant (g) } & \multicolumn{3}{|c|}{ Fresh leaves and flower yield ( $t / h a)$} \\
\hline & 2017 & 2018 & Combined mean & 2017 & 2018 & Combined mean \\
\hline \multicolumn{7}{|l|}{ Plant spacing (cm) } \\
\hline $60 * 45$ & $451.89^{\mathrm{b}}$ & $688.28^{\mathrm{b}}$ & $570.08^{\mathrm{b}}$ & $16.74^{\mathrm{a}}$ & $25.49^{\mathrm{a}}$ & $21.12^{\mathrm{a}}$ \\
\hline $60 * 60$ & $498.06^{\mathrm{b}}$ & $837.22^{\mathrm{ab}}$ & $667.64^{\mathrm{a}}$ & $13.84^{\mathrm{b}}$ & $23.26^{\mathrm{ab}}$ & $18.55^{\mathrm{b}}$ \\
\hline $60 * 75$ & $565.93^{\mathrm{a}}$ & $856.09^{\mathrm{a}}$ & $711.01^{\mathrm{a}}$ & $13.1^{\mathrm{bc}}$ & $19.82^{\mathrm{bc}}$ & $16.56^{\mathrm{b}}$ \\
\hline $60 * 90$ & $615.42^{\mathrm{a}}$ & $895.36^{\mathrm{a}}$ & $755.39^{\mathrm{a}}$ & $11.4^{\mathrm{c}}$ & $16.58^{\mathrm{c}}$ & $13.99^{c}$ \\
\hline LSD (0.05) & 67 & 149.5 & 87.89 & 1.96 & 3.63 & 2.21 \\
\hline Significance & $* * *$ & $*$ & $* *$ & $* * *$ & $* * *$ & $* * *$ \\
\hline \multicolumn{7}{|l|}{ Harvest age (MAT) } \\
\hline 9 & $456.62^{\mathrm{b}}$ & 807.17 & 631.89 & $12.11^{\mathrm{b}}$ & 21.04 & 16.58 \\
\hline $\mathbf{1 0}$ & $598^{\mathrm{a}}$ & 815.17 & 706.58 & $15.09^{\mathrm{a}}$ & 21.17 & 18.13 \\
\hline 11 & $543.86^{\mathrm{a}}$ & 835.38 & 689.62 & $14.1^{\mathrm{a}}$ & 21.65 & 17.88 \\
\hline LSD (0.05) & 58.02 & 129.47 & 76.11 & 1.7 & 3.14 & 1.92 \\
\hline Significance & $* * *$ & NS & NS & $* *$ & NS & NS \\
\hline Spa*HA & $*$ & NS & NS & NS & NS & NS \\
\hline $\mathrm{CV}(\%)$ & 12.86 & 18.67 & 13.3 & 14.6 & 17.44 & 12.9 \\
\hline
\end{tabular}

Means with the same letter at the same column are not significantly different.

Where, MAT $=$ Months after transplanting, LSD $=$ Least significance difference, $\mathrm{CV}=$ Coefficient of variation, $\mathrm{Spa}=$ Spacing, $\mathrm{HA}=$ Harvesting age, $\mathrm{NS}=$ Non significant at $\mathrm{p}<0.05, *=$ Significant at $\mathrm{p}<0.05, * *=$ Significant at $\mathrm{p}<0.01$ and $* * *=$ Significant at $\mathrm{p}<0.001$ probability level

\section{Essential Oil Content (\%)}

Essential oil content was significantly $(\mathrm{p}<0.05)$ affected by plant spacing in 2018 cropping season. The highest $(0.54 \%)$ and least $(0.42 \%)$ essential oil content were obtained at $60 * 75 \mathrm{~cm}$ and $60 * 60 \mathrm{~cm}$ 
Effect of harvesting age and plant spacing on growth, yield and yield component of Lavender (Lavandula angustifolia L.) under Rainfed condition at Hawassa, Southern Ethiopia

plant spacing, respectively (Table 4). Whereas, plant spacing had not a significant ( $\mathrm{p}>0.05)$ effect on essential oil content in 2017 cropping season and combined mean (Table 4).

Based on the combined result, harvesting age had a significant $(\mathrm{p}<0.001)$ effect on essential oil content (Table 4). Similar result was reported by Haileslassie and Kebede (2015) on rose-scented geranium. The highest $(0.67 \%)$ and least $(0.54 \%)$ essential oil content was obtained when lavender was harvested at 11 and 9 MAT, respectively. When harvesting age increases, essential oil content also increased under rainfed condition. This could be due to the presence of more stressed leaves at 11 MAT.

However, the interaction of the plant spacing and harvesting age did not significantly ( $>0.05)$ affect essential oil content (Table 4). Similar result was obtained by Beemnet et al., (2011) on peppermint and Zewdinesh et al. (2011) on Artemisia. Contrasting result was reported by Haileslassie and Kebede (2015) on rose-scented geranium.

\section{Essential Oil Yield/ha (kg)}

The combined result revealed that, the main effect plant spacing, and harvest age had a very highly significant $(\mathrm{p}<0.001)$ effect on essential oil yield/ha (Table 4). Supporting result was reported by Zewdinesh et al. (2011) on Artemisia; Haileslassie and Kebede (2015) on rose-scented geranium and Jimayu et al. (2016) on Lemongrass. The highest (119.2 t) and least (80.06 t) essential oil yield/ha was obtained when lavender was planted at a spacing of $60 * 45 \mathrm{~cm}$ and $60 * 90 \mathrm{~cm}$, respectively (Table 4). This could be due to the presence of many plants per unit area contribute to an increase in fresh leaves and flower yield/ha thereby increased in essential oil yield/ha. The highest (115.5 t) and least (81.63 t) essential oil yield/ha was obtained when Lavender was harvested at 11 and 9 MAT, respectively. As to essential oil content, essential oil yield/ha increased when harvesting age increases. This could be due to an increase in essential oil content would contribute for an increase in essential oil yield/ha.

However, the interaction effect of plant spacing and harvesting age did not significantly ( $>0.05)$ affect essential oil yield/ha (Table 4). Supporting result was reported by Zewdinesh et al. (2011) on Artemisia. Contradicted results were reported by Beemnet et al., (2011) on peppermint and Haileslassie and Kebede (2015) on rose-scented geranium.

Table 4. Effect of plant spacing and harvest age on essential oil content (\%) and essential oil yield/ha (kg) of L. angustifolia L. at Hawassa during 2017 and 2018

\begin{tabular}{|c|c|c|c|c|c|c|c|}
\hline \multirow{2}{*}{$\begin{array}{l}\text { Treatment } \\
\text { Statistics }\end{array}$} & \multirow{2}{*}{$\&$} & \multicolumn{3}{|c|}{ Essential oil content (\%) } & \multicolumn{3}{|c|}{ Essential oil yield/ha $(\mathrm{kg})$} \\
\hline & & 2017 & 2018 & $\begin{array}{l}\text { Combined } \\
\text { mean }\end{array}$ & 2017 & 2018 & $\begin{array}{l}\text { Combined } \\
\text { mean }\end{array}$ \\
\hline \multicolumn{8}{|c|}{ Plant spacing (cm) } \\
\hline $60 * 45$ & & 0.67 & $0.50^{\mathrm{ab}}$ & 0.59 & $112.28^{\mathrm{a}}$ & $126.11^{\mathrm{a}}$ & $119.20^{\mathrm{a}}$ \\
\hline $60 * 60$ & & 0.69 & $0.42^{\mathrm{b}}$ & 0.56 & $95.49^{\mathrm{ab}}$ & $96.34^{\mathrm{bc}}$ & $95.91^{\mathrm{b}}$ \\
\hline $60 * 75$ & & 0.69 & $0.54^{\mathrm{a}}$ & 0.62 & $90.89^{\mathrm{bc}}$ & $106.19^{\mathrm{b}}$ & $98.54^{\mathrm{b}}$ \\
\hline $60 * 90$ & & 0.67 & $0.51^{\mathrm{a}}$ & 0.59 & $76.54^{\mathrm{c}}$ & $83.59^{\mathrm{c}}$ & $80.06^{\mathrm{c}}$ \\
\hline LSD (0.05) & & 0.08 & 0.09 & 0.07 & 17.67 & 14.83 & 9.5 \\
\hline Significance & & NS & $*$ & NS & $* *$ & $* * *$ & $* * *$ \\
\hline \multicolumn{8}{|c|}{ Harvest age (MAT) } \\
\hline 9 & & $0.64^{\mathrm{b}}$ & $0.43^{\mathrm{b}}$ & $0.54^{\mathrm{b}}$ & $76.46^{\mathrm{b}}$ & $86.80^{b}$ & $81.63^{\mathrm{c}}$ \\
\hline 10 & & $0.67^{\mathrm{ab}}$ & $0.45^{\mathrm{b}}$ & $0.56^{\mathrm{b}}$ & $101.56^{\mathrm{a}}$ & $94.74^{\mathrm{b}}$ & $98.15^{\mathrm{b}}$ \\
\hline 11 & & $0.74^{\mathrm{a}}$ & $0.60^{\mathrm{a}}$ & $0.67^{\mathrm{a}}$ & $103.37^{\mathrm{a}}$ & $127.64^{\mathrm{a}}$ & $115.50^{\mathrm{a}}$ \\
\hline LSD (0.05) & & 0.07 & 0.07 & 0.06 & 15.3 & 12.84 & 8.23 \\
\hline Significance & & $*$ & $* * *$ & $* * *$ & $* *$ & $* * * *$ & $* * *$ \\
\hline Spa*HA & & NS & NS & NS & NS & NS & NS \\
\hline $\mathrm{CV}(\%)$ & & 12.66 & 17.61 & 11.68 & 19.27 & 14.72 & 9.88 \\
\hline
\end{tabular}

Means with the same letter at the same column are not significantly different. 
Effect of harvesting age and plant spacing on growth, yield and yield component of Lavender (Lavandula angustifolia L.) under Rainfed condition at Hawassa, Southern Ethiopia

Where, MAT $=$ Months after transplanting, $\mathrm{LSD}=$ Least significance difference, $\mathrm{CV}=$ Coefficient of variation, $\mathrm{Spa}=$ Spacing, $\mathrm{HA}=$ Harvest age, $\mathrm{NS}=$ Non significant at $\mathrm{p}<0.05, *=$ Significant at $\mathrm{p}<0.05, * *=$ Significant at $\mathrm{p}<0.01$ and $* * *=$ Significant at $\mathrm{p}<0.001$

Table5. Effect of plant spacing and harvesting age on plant height (cm) of L. angustifolia L. at Hawassa during 2018

\begin{tabular}{|c|c|c|c|}
\hline \multirow{3}{*}{ Treatment \& Statistics } & \multicolumn{3}{|c|}{ Plant height (cm) } \\
\hline & \multicolumn{3}{|c|}{ Harvesting age(MAT) } \\
\hline & 9 & 10 & 11 \\
\hline \multicolumn{4}{|l|}{ Plant spacing (cm) } \\
\hline $60 * 45$ & $71.93^{\mathrm{abc}}$ & $68.87^{\mathrm{bc}}$ & $75.33^{\mathrm{abc}}$ \\
\hline $60 * 60$ & $75.8^{\mathrm{ab}}$ & $71.53^{\text {abc }}$ & $72.33^{\text {abc }}$ \\
\hline $60 * 75$ & $67.53^{b c}$ & $70.67^{\text {abc }}$ & $76.07^{\text {ab }}$ \\
\hline $60 * 90$ & $68.8^{b c}$ & $79.8^{\mathrm{a}}$ & $65.73^{c}$ \\
\hline LSD (0.05) & \multicolumn{3}{|l|}{9.62} \\
\hline
\end{tabular}

Where, MAT $=$ Months after transplanting and LSD $=$ Least significance difference

Table6. Effect of plant spacing and harvesting age on fresh leaves and flower weight/plant $(g)$ of L. angustifolia L. at Hawassa during 2017

\begin{tabular}{|c|c|c|c|}
\hline \multirow{3}{*}{ Treatment \& Statistics } & \multicolumn{3}{|c|}{ Fresh leaves and flower weight/plant (g) } \\
\hline & \multicolumn{3}{|c|}{ Harvesting age (MAT) } \\
\hline & 9 & $\mathbf{1 0}$ & 11 \\
\hline \multicolumn{4}{|l|}{ Plant spacing $(\mathbf{c m})$} \\
\hline $60 * 45$ & $446.88^{\mathrm{e}}$ & $441.10^{\mathrm{e}}$ & $467.69^{\text {de }}$ \\
\hline $60 * 60$ & $444.57^{\mathrm{e}}$ & $532.79^{\text {bcde }}$ & $516.82^{\text {cde }}$ \\
\hline $60 * 75$ & $483.10^{\text {de }}$ & $636.05^{\mathrm{b}}$ & $578.63^{\text {bcd }}$ \\
\hline $60 * 90$ & $451.91^{\mathrm{e}}$ & $782.05^{\mathrm{a}}$ & $612.31^{\mathrm{bc}}$ \\
\hline LSD(0.05) & 116.05 & & \\
\hline
\end{tabular}

Where, MAT $=$ Months after transplanting and LSD $=$ Least significance difference

\section{CONCLUSION AND RECOMMENDATION}

The study showed that, the highest number of branches/plant (180.7) and fresh leaves and flower weight/plant $(755.39 \mathrm{~g})$ was obtained at the spacing of $60 * 90 \mathrm{~cm}$; fresh leaves and flower yield/ha $(21.12 \mathrm{t})$ and essential oil yield/ha $(119.2 \mathrm{~kg})$ was obtained at a spacing of $60 * 45 \mathrm{~cm}$. Harvesting age also had a significant influence on essential oil content and essential oil yield/ha; but it did not significantly influence plant height, number of branches per plant, fresh leaves and flower weight/plant and fresh leaves and flower yield/ha. The highest essential oil content $(0.67 \%)$ and essential oil yield/ha $(115.5 \mathrm{~kg})$ were obtained at $11 \mathrm{MAT}$; however, the least values $(0.54 \%$ and $81.63 \mathrm{~kg}$, respectively) were obtained at 9 MAT. The interaction of plant spacing and harvesting age had not a significant influence on plant height, number of branches per plant, fresh leaves and flower weight/plant, fresh leaves and flower yield/ha, essential oil content and essential oil yield/ha. Therefore, it was concluded that further investigation is needy by adding additional levels of harvesting age above 11MAT to investigate at which age the essential oil yield/ha will be declined. But, for the time being until another investigation obtained, at Hawassa and a place where having similar agroecology, it is highly recommended to plant Lavender at a spacing of $60 * 45 \mathrm{~cm}$ and harvest it at 11MAT to get the highest essential oil yield/ha.

\section{ACKNOWLEDGEMENT}

Ethiopian Institute of Agricultural Research (EIAR) and Wondo Genet Agricultural Research Center are acknowledged for financial and technical support of this study. We are also a grateful thanks and appreciation to Mr. Yigermal Molla and Mr. Admasu Usur for their technical support.

\section{REFERENCES}

[1] Adsersen, A., B. Gauguin, Gudiksen L. and Jager A.K., 2005. Screening of plants used in Danish folk medicine to treat memory dysfunction for acetylcholinesterase inhibitory activity. Journal of Ethnopharmacology 104:418-422. 
Effect of harvesting age and plant spacing on growth, yield and yield component of Lavender (Lavandula angustifolia L.) under Rainfed condition at Hawassa, Southern Ethiopia

[2] Beemnet, M. K., Solomon, A. M. and Jaime, A. T. da Silva, 2011. Agronomic Characters, Leaf and Essential Oil Yield of Peppermint (Mentha piperita L.) As Influenced by Harvesting Age and Row Spacing. Medicinal and Aromatic Plant Science and Biotechnology 5(1) 49 - 53.

[3] Cavanagh, H. M. A., and Wilkinson, J. M., 2005. Lavender essential oil: a review healthcare infection. Aust. Infect. Control 10, 35-37.

[4] Chu, C.J. and K.J. Kemper, 2001. Lavender (lavandula ssp.). Retrieved July 24, 2008 from http://www.longwoodherbal.org/lavender/lavender.pdf.

[5] Daniel Bisrat, Solomon Abate and Wossen Kebede, 2009. Laboratory manual for plant products analysis. Technical manual. Ethiopian Institute of Agricultural Research,1 (23): 4 -6.

[6] Degu Basazinew and Tesfaye Bizuayehu, 2016. Effects of inter and intra row spacing on growth, yield and yield components of Roselle (Hibiscus sabdariffa L.). International Journal of Advanced Biological and Biomedical Research, 5(1), 260-274.

[7] El Naim, A.M., Khaliefa, E.H., Ibrahim, K.A., Ismaeil, F.M., Zaied, M.B., 2012. Growth and yield of Roselle (Hibiscus sabdariffa L.) as influenced by plant population in Arid tropic of Sudan under rain-fed. Int. J. Agr. Forest., 2(3), 88-91.

[8] Haileslassie Gebremeskel and Kebede Woldetsadik, 2015. Effect of plant spacing and harvesting age on growth, biomass and oil yield of rose-scented geranium (Pelargonium graveolens L. Herit). Basic Research Journal of Agricultural Science and Review ISSN 23156880 Vol. 4(3) pp. 094-101

[9] Jimayu Getachew, Gebre Aynalem. And Mengesha Beemnet, 2016. Response of Lemongrass (Cymbopogon Citratus L) Varieties for Different Intra and Inter row spacing at Wondo genet, Southern Ethiopia. Acad. Res. J. Agri. Sci. Res. 4(6): 279-284

[10] Rahimmalek M, Bahreininejad B, Khorrami M, Sayed TBE, 2009. Genetic variability and geographical differentiation in Thymus daenensissubsp. daenensis Cleak, an endangered aromatic and medicinal plant as revealed by Inter Simple Sequence Repeat (ISSR) markers. Biochem. Genet, 47, 831-842.

[11] Renaud, E.N.C., Charles, D.J., Simon, J.E., 2001. Essential oil quantity and composition from 10 cultivars of organically grown lavender and lavandin. J. Essent. Oil Res., 13, 269-273.

[12] Sakamoto, R., K. Minoura, A. Usui, Y. Ishizuka and S. Kanba, 2005. Effectiveness of aroma on work efficiency: Lavender aroma during recesses prevents deterioration of work performance. Chemical Senses30:683-691.

[13] SAS inst., 2000. SAS (Statistical Analysis System), 1996. SAS/STAT. Guide Version 9. SAS, Institute Inc. Raleigh, North Carolina: USA.

[14] Shafie MSB, Zain HSM and Shah MS., 2009. Study of genetic variability of Wormwood capillary (Artemisia capillaris) using inter simple sequence repeat (ISSR) in Pahang region, Malaysia. Plant Omics J, 2(3), 127-134.

[15] Shawl, A.S.; Kumar, S., 2000. Potential of Lavender oil industry in Kashmir. J. Med. Arom. Plants, 22:319-321. J. Med. Arom. Plant Sci. 22 (2000) 319.

[16] Tadesse Nibret, Gebere Aynalem, Lulie Belstie and Hordofa Melkamu, 2016. Influence of plant population density on growth and yield of Stevia (Stevia rebaudiana Bertoni L.) at Wondo Genet South Ethiopia. Acad. Res. J. Agri. Sci. Res. 4(6): 321-329

[17] Zewdinesh Damtew, Bizuayehu Tesfaye and Daniel Bisrat, 2011. Leaf, Essential Oil and Artemisinin Yield of Artemisia (Artemisia annua L.) As Influenced by Harvesting Age and Plant Population Density. World Journal of Agricultural Sciences 7 (4): 404-412, 2011.

Citation: Basazinew Degu \& Sulti Amano (2020). "Effect of harvesting age and plant spacing on growth, yield and yield component of Lavender (Lavandula angustifolia L.) under Rainfed condition at Hawassa, Southern Ethiopia". ", International Journal of Research Studies in Agricultural Sciences (IJRSAS), 6(6), pp. 17-24. DOI: http://dx.doi.org/10.20431/2454-6224.0606003

Copyright: () 2020Authors. This is an open-access article distributed under the terms of the Creative Commons Attribution License, which permits unrestricted use, distribution, and reproduction in any medium, provided the original author and source are credited. 